\title{
COMPARISON OF STREAM NUTRIENT CONDITIONS IN A SUBTROPICAL LOWLAND WATERSHED TO EPA SUGGESTED CRITERIA
}

\author{
April Mason and Y. Jun Xu \\ School of Renewable Natural Resources \\ Louisiana State University Agricultural Center, Baton Rouge, LA 70803 \\ Johnny M. Grace \\ USDA Forest Service - Southern Research Station \\ 520 Devall Drive, Auburn, AL 36830
}

\begin{abstract}
Nutrients such as nitrogen, phosphorus and organic carbon are essential to the health and diversity of stream ecosystems. However, excess nutrients can cause eutrophication, resulting in overgrowth of aquatic plants and decline of the ecosystem diversity. A paired-watershed study was initiated in a subtropical forested watershed within the Ouachita River Basin in Louisiana to identify stream nutrient conditions with respect to the U.S. Environmental Protection Agency (EPA) suggested criteria, and to examine changes in nutrient levels following timber harvesting operations with and without BMP implementation. Nutrient concentrations were measured in both storm runoff and monthly stream water samples collected at 11 sites in the headwater streams. Water samples were analyzed for total and dissolved phosphorus, nitrite, nitrate, ammonia, total Kjeldahl nitrogen, along with total and dissolved organic and inorganic carbon. The preliminary results show that the low-order streams in these watersheds frequently exceeded the suggested nitrogen criteria before any harvesting activities were initiated. Average nitrite/nitrate at all monitoring sites $\left(0.172-0.410 \mathrm{mgL}^{-1}\right)$ was significantly higher than EPA's recommended level $\left(0.067 \mathrm{mg} \mathrm{L}^{-1}\right)$, especially during rainstorm events and warmer months. Total phosphorus varied from $0.028 \mathrm{mg} \mathrm{L}^{-1}-0.104 \mathrm{mg} \mathrm{L}^{-1}$, which were within the EPA recommendation levels. Total organic carbon showed high levels in both monthly and storm water samples at most of the monitoring sites.
\end{abstract}

Keywords. Stream water quality, nutrient criteria, TMDLs, nitrate/nitrite, phosphorus, carbon ,

\section{INTRODUCTION}

Nutrients including nitrogen $(\mathrm{N})$, phosphorus $(\mathrm{P})$, and carbon $(\mathrm{C})$ are necessary for stream health and diversity. Excess nutrients cause eutrophication, which alters biological production and diversity in a majority of affected areas (e.g. Whitton, 1975; Leonard et al., 1979; Howarth et al., 1990; Vitousek, 1994; Freedman, 1995). Because ordinarily limiting nutrients are found to be in excess, algal blooms occur more frequently and more severe (Young et al., 1995), often resulting in anoxic conditions. Phosphorous is strongly correlated with primary production and is typically the most limiting nutrient in freshwater systems (Dillon and Kirchner, 1975; Young et al., 1995), thus is the primary factor controlling eutrophication (Kumar, 1992; Soranno et al., 1996).

Nutrient loading of water bodies can occur through point (direct input) or nonpoint (diffuse) sources. Point source pollution has been effectively controlled, however nonpoint source pollution continues to plague waterways because of the difficulty to identify, isolate, and control pollution sources (Ice, 2004). Nonpoint source nutrients from agricultural and urban development runoff contribute to eutrophication in freshwater systems (Isermann, 1990; Soranno et al., 1996; Carpenter et al., 1998). Watershed characteristics, such as the local geology, soils, and topography, and land use impact the potential for nonpoint nutrient loading (Bedford, 1996; Soranno et al., 1996) resulting in overgrowth of aquatic plants and a decline in dissolved oxygen and ecosystem diversity.

The Environmental Protection Agency (EPA) has developed a set of suggested water quality criteria for ecoregions across the nation. The ecoregions are further subdivided into subecoregions to represent localized conditions. These data are to support the development of nutrient criteria (EPA, 2000) such as Total Maximum Daily Loads (TMDLs) to comply with the Clean Water Act section 303(c). Data presented include a range of concentrations found for total phosphorus, dissolved phosphorus, and nitrate/nitrite and the $25^{\text {th }}$ percentile (P25) average for each element. The objective of this paper was to determine if nutrient concentrations found in a Northern Louisiana subwatershed meet the criteria suggested by the EPA in its Ambient Water Quality Criteria Recommendations for Ecoregion IX. 


\section{METHODS}

Study Area

Flat Creek Watershed is located in the western part of the Ouachita River Basin in central Louisiana. Ouachita River Basin is $41,439 \mathrm{~km}^{2}$ with flat to slightly rolling topography. Forestry is the dominant land use in Flat Creek Watershed with $61 \%$ of land followed by rangeland with $21 \%$ (LDEQ, 2001). Flat Creek's drainage area is approximately $350 \mathrm{~km}^{2}$. Four streams in the Flat Creek Watershed were sampled: Spring Creek, Turkey Creek, Flat Creek, and Big Creek.

Louisiana's climate is semi-tropical with hot, humid summers and mild winters. Average temperatures range from $36.2^{\circ} \mathrm{F}$ to $93.3^{\circ} \mathrm{F}\left(2.3^{\circ} \mathrm{C}-34.1^{\circ} \mathrm{C}\right)$ and average rainfall is about $1500 \mathrm{~mm} \mathrm{yr}^{-1}$.

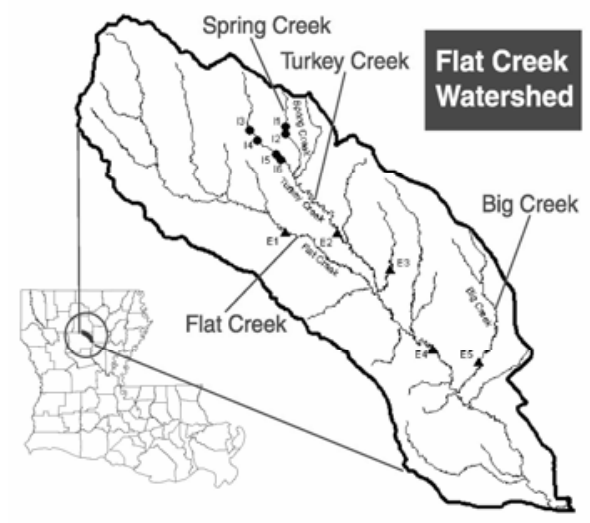

Figure 1. Geographical location of the Flat Creek Watershed and water quality monitoring sites.

Water Collection

Eleven sites were visited monthly from December 2005 to October 2006 (Figure 1). In-situ water quality measurements, including dissolved oxygen, temperature, conductivity, and $\mathrm{pH}$ were taken at each site using an YSI 556 (Yellow Springs Instruments, Yellow Springs, OH, USA). Water samples collected were analyzed for nutrients including nitrate/nitrite, total Kjeldahl nitrogen (TKN), ammonium, and total and dissolved phosphorus. Water was also analyzed for total and dissolved organic and inorganic carbon using a Shimadzu Total Organic Carbon Analyzer (TOC-V CSN Shimadzu Corporation, Kyoto, Japan). Carbon data is currently available from January 2006 - July 2006. Streamflow was also recorded at each site. In addition, storm water samples were collected at six of the eleven locations with automated ISCO samplers (model 6712, Teledyne Isco, Inc., Lincoln, NE, USA). Water samples were analyzed for nutrients and total and dissolved organic carbon.

\section{RESULTS}

Seasonal Variation in N, P and C concentrations

Total phosphorus from December 2005 to October 2006 averaged $0.028 \mathrm{mg} \mathrm{L}^{-1}-0.104 \mathrm{mg} \mathrm{L}^{-1}$ at the eleven sites sampled (Figure 2). All sites had average concentrations less than EPA's P25 of $0.385 \mathrm{mg} \mathrm{L}^{-1}$ and well within the range reported of $0.33 \mathrm{mg} \mathrm{L}^{-1}-3.738 \mathrm{mg} \mathrm{L}^{-1}$. Storm events did not elevate phosphorus concentrations $\left(0.051 \mathrm{mg} \mathrm{L}^{-1}-0.061 \mathrm{mg} \mathrm{L}^{-1}\right)$ in the streams sampled. Dissolved phosphorus averaged 0.012 $\mathrm{mg} \mathrm{L}^{-1}$ to $0.054 \mathrm{mg} \mathrm{L}^{-1}$ from December 2005 to October 2006. Storm events during this period had dissolved phosphorus ranging from $0.019 \mathrm{mg} \mathrm{L}^{-1}$ to $0.029 \mathrm{mg} \mathrm{L}^{-1}$. Particulate phosphorus averaged 0.004 $\mathrm{mg} \mathrm{L}^{-1}$ to $0.070 \mathrm{mg} \mathrm{L}^{-1}$ with storm samples averaging $0.023 \mathrm{mg} \mathrm{L}^{-1}$. There was not a clear seasonal pattern in particulate phosphorus. 


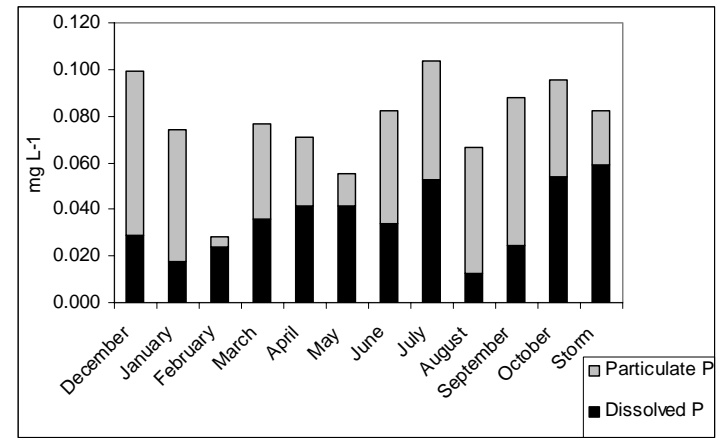

Figure 2. Seasonal and storm variation of total phosphorus and dissolved phosphorus in Flat Creek Subwatershed from December 2005 to October 2006 and for storms sampled (EPA's P25 for this subecoregion is $0.385 \mathrm{mg} \mathrm{L}^{-1}$ ).

Nitrate/nitrite peaked in August (0.69 $\left.\mathrm{mg} \mathrm{L}^{-1}\right)$ and decreased in September back to levels near July's (Figure 3). Average nitrate/nitrite concentration was $0.13 \mathrm{mg} \mathrm{L}^{-1}$ in December and after its peak in August, fell to $0.37 \mathrm{mg} \mathrm{L}^{-1}$ in October. Average nitrate/nitrite concentrations during storm events showed a wider range from $0.11 \mathrm{mg} \mathrm{L}^{-1}$ to $1.49 \mathrm{mg} \mathrm{L}^{-1}$; however the mean storm nitrate/nitrite $\left(0.35 \mathrm{mg} \mathrm{L}^{-1}\right)$ was lower than that found during monthly sampling.

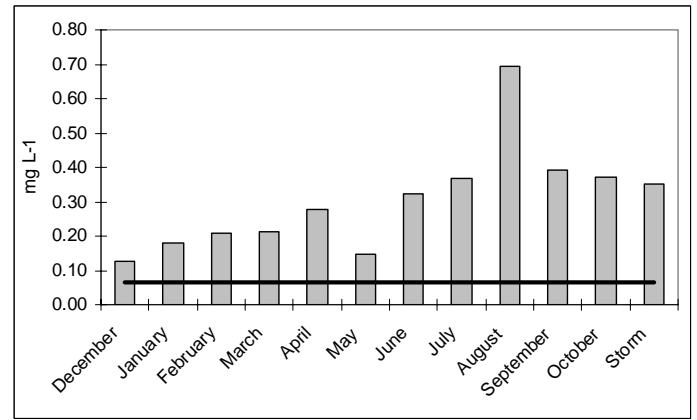

Figure 3. Average nitrate/nitrite concentrations for all sites sampled from December 2005 to October 2006 and average for storm events sampled (Line at $0.067 \mathrm{mg} \mathrm{L}^{-1}$ represents the EPA's P25 for this subecoregion).

Organic carbon peaked in March (22.96 $\mathrm{mg} \mathrm{L}^{-1}$ ) and decreased from April to July (20.45 $\mathrm{mg} \mathrm{L}^{-1}$ to 9.82 $\mathrm{mg} \mathrm{L}^{-1}$ ) (Figure 4). Total inorganic carbon increased from January to July (2.22 $\mathrm{mg} \mathrm{L}^{-1}$ to $12.46 \mathrm{mg} \mathrm{L}^{-1}$ ). There was a general trend of increased TOC with increasing nitrate/nitrite, while TIC decreased after March’s peak (Figure 5).

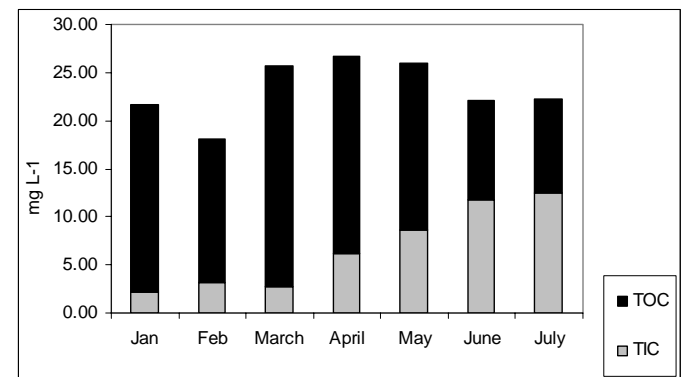

Figure 4. Average total organic carbon (TOC) and total inorganic carbon (TIC) concentrations for all sites sampled from January 2006 to July 2006. 
Spatial Variation in N, P and C Concentrations

Average nitrate/nitrite concentrations for each site varied from $0.19 \mathrm{mg} \mathrm{L}^{-1}$ to $0.39 \mathrm{mg} \mathrm{L}^{-1}$ (Table 1 ). There was no clear spatial trend in terms of stream order. Although nitrate/nitrite concentrations appeared to increase from upstream to downstream on Turkey Creek $\left(0.19 \mathrm{mg} \mathrm{L}^{-1}\right.$ to $\left.0.37 \mathrm{mg} \mathrm{L}^{-1}\right)$, average concentrations remained the same on Flat Creek $\left(0.30 \mathrm{mg} \mathrm{L}^{-1}\right)$ and decreased on Spring Creek $\left(0.27 \mathrm{mg} \mathrm{L}^{-1}\right.$ to $0.22 \mathrm{mg} \mathrm{L}^{-1}$ ).

Average total phosphorus concentrations for each site were $0.037 \mathrm{mg} \mathrm{L}^{-1}-0.128 \mathrm{mg} \mathrm{L}^{-1}$ (Table 1). Total phosphorus tended to increase from upstream to downstream. On Turkey Creek, average TP was $0.065 \mathrm{mg}$ $\mathrm{L}^{-1}$ at the headwaters and increased downstream at site I6 to $0.127 \mathrm{mg} \mathrm{L}^{-1}$. On Spring Creek, TP increased from $0.037 \mathrm{mg} \mathrm{L}^{-1}$ to $0.048 \mathrm{mg} \mathrm{L}^{-1}$. Downstream of the confluence of Spring and Turkey Creeks, TP averaged $0.053 \mathrm{mg} \mathrm{L}^{-1}$. Flat Creek also had an increase in TP from upstream $\left(0.0065 \mathrm{mg} \mathrm{L}^{-1}\right)$ to downstream (0.101 $\left.\mathrm{mg} \mathrm{L}^{-1}\right)$. Total phosphorus during storm events also had a slight trend of increasing TP from upstream to downstream. Although the two sites sampled on Spring Creek were about the same $(0.063 \mathrm{mg}$ $\mathrm{L}^{-1}$ upstream, $0.060 \mathrm{mg} \mathrm{L}^{-1}$ downstream), there was a clearer trend of increasing TP in Turkey Creek $(0.051$ mg $\left.\mathrm{L}^{-1}-0.068 \mathrm{mg} \mathrm{L}^{-1}\right)$. Dissolved phosphorus had some spatial trends in Turkey Creek (increasing downstream from $0.030 \mathrm{mg} \mathrm{L}^{-1}$ to $0.062 \mathrm{mg} \mathrm{L}^{-1}$ ) and Flat Creek (0.065 mg L $\mathrm{m}^{-1}$ to $0.101 \mathrm{mg} \mathrm{L}^{-1}$ ) (Table 1$)$.

There was no clear spatial trend in total organic carbon (TOC) concentrations which varied from 8.48 $\mathrm{mg} \mathrm{L}^{-1}$ to $22.37 \mathrm{mg} \mathrm{L}^{-1}$ across the watershed. Total inorganic carbon (TIC, $4.15 \mathrm{mg} \mathrm{L}^{-1}$ to $9.35 \mathrm{mg} \mathrm{L}^{-1}$ ) also did not show a clear spatial trend. However, the ratio between TOC and TIC appeared to increase from the upstream to the downstream locations.

Table 1. Spatial patterns of average total phosphorus (TP), dissolved phosphorus (DP), nitrate/nitrite $\left(\mathrm{NO}_{3} / \mathrm{NO}_{2}\right)$, total inorganic carbon (TIC), and total organic carbon (TOC) in the Flat Creek

Subwatershed from December 2005 to October 2006 for each of the respective sites.

\begin{tabular}{ccccccc}
\hline & $\begin{array}{c}\text { Stream } \\
\text { Order }\end{array}$ & TP & DP & $\mathrm{NO}_{3} / \mathrm{NO}_{2}$ & $\mathrm{TIC}$ & $\mathrm{TOC}$ \\
\hline Spring Cr & & & & & & \\
I1 & 1st & 0.037 & 0.021 & 0.27 & 4.15 & 8.48 \\
I2 & 1st & 0.048 & 0.019 & 0.22 & 7.95 & 10.48 \\
Turkey & & & & & & \\
Cr & & & & & & \\
I3 & 1st & 0.065 & 0.030 & 0.19 & 7.55 & 20.35 \\
I4 & 1st & 0.086 & 0.036 & 0.23 & 9.35 & 19.29 \\
I5 & 1st & 0.128 & 0.062 & 0.29 & 7.98 & 22.37 \\
I6 & 1st & 0.127 & 0.044 & 0.37 & 8.68 & 20.89 \\
E2 & 2nd & 0.053 & 0.037 & 0.26 & 4.69 & 17.67 \\
Flat Cr & & & & & & \\
E1 & 2nd & 0.065 & 0.034 & 0.30 & 6.84 & 21.56 \\
E4 & 3rd & 0.101 & 0.038 & 0.30 & 8.09 & 17.75 \\
Fish Cr & & & & & & \\
(E3) & 1st & 0.043 & 0.016 & 0.22 & 4.19 & 13.33 \\
Big Cr & & & & & & \\
(E5) & 1st & 0.048 & 0.020 & 0.39 & 5.52 & 11.79 \\
\hline
\end{tabular}




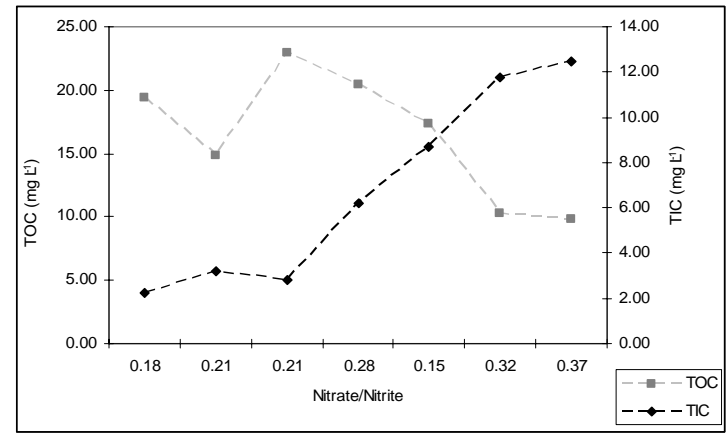

Figure 5. The relationship between monthly total organic carbon (TOC), total inorganic carbon (TIC) and nitrate/nitrite from January to July, 2006.

\section{DISCUSSION}

Spatiotemporal Variations in Stream Nutrient Concentrations

There was no clear spatial trend in nitrate/nitrite concentrations. The streams in this subtropical watershed showed a higher concentration of nitrate/nitrite during the summer, coinciding with the decreasing trend of organic carbon and the increasing inorganic carbon (Fig. 5). The nitrate/nitrite peak in August may have been a direct result of extremely low water and high temperature during the season. Localized stream conditions such as channel morphology and stream habitat can alter flow, stream temperature and organic material sources, indirectly affecting the seasonality of nitrate/nitrite concentrations.

Phosphorus did not show a seasonal trend. However, an increasing trend of TP and DP from upstream to downstream was found. E2 on Turkey Creek tended to be lower than sites upstream, but the site is located downstream of the confluence of Spring Creek and Turkey Creek. Phosphorus concentrations at E2 reflected this mixing of water with concentrations higher than Spring Creek and lower than Turkey Creek. Phosphorus movement tends to coincide with the movement of soil particles, which may be transported downstream corresponding with increased total phosphorus shown in this preliminary dataset.

\section{Applicability of EPA Suggested Criteria}

Total phosphorus was well below EPA's suggested criteria for this ecoregion. Even during storm events in which an increase of runoff and thus excess nutrient transport is expected, TP concentrations were low. Nitrogen, however, exceeded the EPA's P25 of $0.067 \mathrm{mg} \mathrm{L}^{-1}$ during every month sampled. The range of nitrate/nitrite $\left(0.13 \mathrm{mg} \mathrm{L}^{-1}\right.$ to $\left.0.37 \mathrm{mg} \mathrm{L}^{-1}\right)$ fell within the range reported by EPA for this ecoregion $(0.005$ 6.245). Although average nitrate/nitrite in Flat Creek Subwatershed was within this large range reported for this ecoregion by the EPA, it is still an order of magnitude higher than the P25 which would be utilized for regulation. Due to natural conditions, it may not be possible to reduce nitrate/nitrite in Flat Creek to the EPA's P25. The balance of various nitrogen species (i.e. ammonium, nitrate/nitrite) present in a stream can be oxygen dependent (Margolis et al., 2001). Louisiana's streams consistently have low dissolved oxygen, which may contribute to nitrate/nitrite levels above EPA's P25. Considering that the sites are in a rural forested area, these streams are experiencing near natural conditions and are not being heavily influenced by land use changes.

Carbon is currently not measured by the EPA for use in their suggested criteria. It has been found that carbon can affect nitrification in streams (Strauss et al., 2002) indicating the potential importance of measuring carbon in streams. The general trend in figure 5 may indicate that the carbon concentrations present in the stream may be influencing nitrate/nitrite levels.

\section{CONCLUSIONS}

Total phosphorus at all sites in this investigation had average concentrations less than EPA's P25 of $0.385 \mathrm{mg} \mathrm{L}^{-1}$ and within the range reported by the EPA for this ecoregion. Average nitrate/nitrite concentrations during storm events showed a wider range than monthly samplings and the mean storm nitrate/nitrite concentrations were lower than that found during monthly samplings. Based on this preliminary dataset, EPA's suggested criteria for nitrate/nitrite may be too low for streams in Flat Creek to attain, whereas the phosphorus criteria appears attainable. Additionally, carbon concentrations in natural streams may be a valuable indicator for determining stream health combined with the nutrient data already 
collected.

\section{ACKNOWLEDGEMENTS}

This research was supported by the Louisiana Department of Environmental Quality and the USDA Forest Service Southern Research Station. We thank Plum Creek Timber Company for providing research site and field support.

\section{REFERENCES}

Bedford, B. L. 1996. The need to define hydrologic equivalence at the landscape scale for freshwater wetland mitigation. Ecological Applications 6:57-68.

Carpenter, S. R., N. E. Caraco, D. L. Correll, R. W. Howarth, A. N. Sharpley, and V. H. Smith. 1998. Nonpoint pollution of surface waters with phosphorus and nitrogen. Ecological Applications 8:559-568.

Dillon, P. J. and W. B. Kirchner. 1974. The effects of geology and land use on the export of phosphorus from watersheds. Water Research 9:135-148.

EPA. 2000. Ambient water quality criteria recommendations: Information supporting the development of state and tribal nutrient criteria. Rivers and streams in nutrient ecoregion IX. EPA 822-B-00-019.

Freedman, B. 1995. Environmental Ecology: The ecological effects of pollution, disturbance, and other stresses, 2nd ed. Academic Press, San Diego.

Howarth, R. W., J. R. Fruci, and D. Sherman. 1990. Inputs of sediment and carbon to an estuarine ecosystem. Ecological Applications 1:27-39.

Ice, G. 2004. History of innovative best management practice development and its role in addressing water quality limited waterbodies. Journal of Environmental Engineering, 130, 684-689.

Isermann, K. 1990. Share of agriculture in nitrogen and phosphorus emissions into the surface waters of Western-Europe against the background of their eutrophication. Fertilizer Research 26 (1-3): 253-269.

Kumar, R., R. S. Ambasht, and N. K. Srivastava. 1992. Conservation efficiency of five common riparian weeds in movement of soil, water and phosphorus. Journal of Applied Ecology 29:737-744.

LDEQ. 2001 Flat Creek Watershed TMDL for oxygen demand. Louisiana Department of Environmental Quality, Office of Environmental Assessment, Environmental Technology Division. Baton Rouge, Louisiana.

Leonard, R. L., l. A. Kaplan, J. F. Elder, R. N. Coats, and C. R. Goldman. 1979. Nutrient transport in surface runoff from a subalpine watershed, Lake Tahoe Basin, California. Ecological Monographs 49:281-310.

Margolis, B.E., Castro, M.S., \& Raesly, R.L. 2001. The impact of beaver impoundments on the water chemistry of two Appalachian streams. Canadian Journal of Fisheries \& Aquatic Sciences 58:22712283.

Soranno, P. A., S. L. Hubler, and S. R. Carpenter. 1996. Phosphorus loads to surface waters: A simple model to account for spatial pattern of land use. Ecological Applications 6:865-878.

Strauss, E.A., N.L. Mitchell, and G.A. Lamberti. 2002. Factors regulating nitrification in aquatic sediments: effects of organic carbon, nitrogen availability, and pH. Canadian Journal of Fisheries \& Aquatic Sciences 59:554-563.

Vitousek, P.M. 1994. Beyond global warming - Ecology and Global Change Ecology 75 (7): 1861-1876.

Whitton, B. A. 1975. River Ecology. University of California Press, Berkeley.

Young, W. J., F. M. Marston, and J. R. Davis. 1995. Nutrient exports and land use in Australian catchments. Journal of Environmental Management 47:165-183. 